\title{
Cationic Bioactive Peptide from the Seeds of Benincasa hispida
}

\author{
Sunayana Sharma, ${ }^{1}$ Hirday Narain Verma, ${ }^{1}$ and Nilesh Kumar Sharma ${ }^{1,2}$ \\ ${ }^{1}$ School of Life Sciences, Jaipur National University, Jaipur 302025, India \\ ${ }^{2}$ Department of Molecular Biology and Genetics, Dr. D. Y. Patil Vidyapeeth, Dr. D. Y. Patil Biotechnology and Bioinformatics Institute, \\ Mumbai-Bangalore Highway, Tathawade, Pune 411033, India
}

Correspondence should be addressed to Nilesh Kumar Sharma; nilesh.sharma@dpu.edu.in

Received 18 October 2013; Revised 3 March 2014; Accepted 4 March 2014; Published 16 April 2014

Academic Editor: Tzi Bun Ng

Copyright (C) 2014 Sunayana Sharma et al. This is an open access article distributed under the Creative Commons Attribution License, which permits unrestricted use, distribution, and reproduction in any medium, provided the original work is properly cited.

A designated bioactive peptide "Hispidalin" purified from the seeds of Benincasa hispida, which is a medicinal plant, belongs to Cucurbitaceae family. Purification was achieved by using a procedure consisting of extraction from potassium phosphate buffer followed by FPLC and HPLC steps. Based on amino acid residue, this peptide is amphipathic and basic with one net positive charge having isoelectric $\mathrm{pH}$ 8.1. This peptide is without sulphur containing amino acid suggesting its extended conformation lacking double bond secondary structure. The results obtained from MALDI-TOF suggested that Hispidalin is of molecular mass $5.7 \mathrm{KDa}$ with 49 amino acid residues and confirmed SDS-PAGE resolved $\sim 6.0 \mathrm{KDa}$ protein band. This novel and unknown peptide "Hispidalin" showed broad and potent inhibitory effects against various human bacterial and fungal pathogens; its growth inhibition was significantly comparable with commercial antibacterial and antifungal drugs. The Hispidalin at $40 \mu \mathrm{g} / \mathrm{mL}$ concentration exhibited 70.8\% DPPH free radical-scavenging activity and 69.5\% lipid peroxide inhibition. Thus, in the present study, Hispidalin demonstrated remarkable antimicrobial and antioxidant potentials from the seeds of B. hispida.

\section{Introduction}

Plants are one of the major sources of peptide. Potentially, peptides have considerable medical importance since they [1] affect the stability and sensory quality of plant foods [2]. Research on bioactive proteins/peptide has been increasing including work on the development of pathogen resistant and antimicrobial compounds [2-6]. In recent years, extensive scientific evidence has been provided for the existence of biological active peptides and proteins derived from plants that might have beneficial effects upon human health [6-12]. Peptides have certain biological activities like antimicrobial and antioxidant activities $[2,4,6,13]$. Several plants in the family Cucurbitaceae have been widely used as medicine in many countries of Asia including India. B. hispida commonly known as wax guard has been used in treatment of gastrointestinal problems [14], antidepressant-like activity [15], antinociceptive, antipyretic [16], anticompulsive effects [17], and antimicrobial activity [18]. Plants are rich in a wide variety of protein that has found antimicrobial properties $[1,2,6,11,19]$. Plants do not have an immune system directly comparable with that of animals. Thus, to protect themselves from infection by a variety of pathogens, plants have evolved a host of defense mechanisms $[2,4,12,19]$. In recent decades, a number of antimicrobial peptides (AMPs) have been identified or predicted from various organisms including plant sources. AMPs in general consist of 10-50 amino acid residues [2, 13, 19]. These peptides do not have any specific consensus amino acid sequences that are responsible for their biological activity, but most of them maintain certain common features, such as containing positive charge and relatively hydrophobic and amphipathic structure. Antimicrobial proteins are produced by many organisms including vertebrates, invertebrates, plants, and fungi $[5,12$, $20,21]$. They serve to protect the organisms from pathogenic bacteria and fungus, which would bring devastating damage. Several plant proteins capable of inhibiting the growth of agronomically important pathogens have been isolated during the last few years $[4,8,20]$. Cationic peptides vary considerably in sequence and structure, with a few common features. Cationic peptides are amphipathic meaning they possess both a hydrophobic region that interacts with lipids 
and a positively charged hydrophilic region that interacts with water or negatively charged residues $[3,4,8,19,22]$. This feature allows the peptides to interact well with membranes that are composed of amphipathic molecules, especially negatively charged bacterial membranes. For the most part, animal cells tend to have membranes with no net charge so they are unaffected by cationic peptides $[5,12,21]$. The findings of several studies have evidenced that protein/peptide from animal and plant proteins can act as direct scavengers of diverse free radicals or behave as antioxidants in model systems $[9,12,23-25]$. In recent years, the antioxidant activities of proteins/peptides hydrolysates from plant-derived proteins, including Sphenostylis stenocarpa [23], hemp seed [9], phaseolin and bean [24], and Jatropha curcas [26], have been evaluated using several in vitro antioxidant evaluation systems such as diphenyl-1-picryhydradzyl (DPPH) and linoleic acid oxidation. The antioxidant properties of these peptides largely depend on the peptide structure, amino acid composition, and their molecular mass [9, 23, 24, 26]. In the present findings, we have attempted to report first unknown peptide designated as Hispidalin from $B$. hispida seeds displaying remarkable and promising antimicrobial and antioxidant activity. Hispidalin primary structure differs from all other known plant proteins. The findings will lead to development of bioactive peptide having broad application in pharmaceutical and therapeutic industry.

\section{Material and Method}

2.1. Biological Materials. The fresh fruit of B. hispida is collected from Agra city of Uttar Pradesh in January 2009. Seeds were separated from fruit and oven-dried at $40^{\circ} \mathrm{C}$ for $48 \mathrm{~h}$. All clinical isolates of bacteria and fungus were obtained from patients at the Microbiology Department, SMS Hospital Jaipur.

2.2. Isolation Procedure. Five hundred gram seeds of $B$. hispida were crushed in the mortar pastel; paste was made with acetone and left covered overnight $(16 \mathrm{~h})$ at normal temperature, then suspended in extraction buffer I of $20 \mathrm{mM}$ potassium phosphate buffer, $\mathrm{pH} 6.5,5.0 \mathrm{mM}$ EDTA, and $1.0 \mathrm{mM}$ DTT for $3 \mathrm{~h}$, and centrifuged $10000 \mathrm{rpm}$ for $10 \mathrm{~min}$ at $4^{\circ} \mathrm{C}$. The supernatant containing soluble proteins was collected and designated fraction I. The pellet was resuspended in extraction buffer I, centrifugation step was repeated, and the supernatants were pooled. The remaining pellet was resuspended in extraction buffer II of $20 \mathrm{mM}$ potassium phosphate buffer, pH 6.5 containing EDTA, DTT, and urea in concentrations of $2 \mathrm{mM}, 1 \mathrm{mM}$, and $4 \mathrm{M}$, respectively, with $2 \%$ Triton X 100. Further, it was homogenized three times and centrifuged at $10,000 \times \mathrm{g}$ for $10 \mathrm{~min}$ at $4^{\circ} \mathrm{C}$. The supernatant was collected and mixed with fraction I. Thereafter, $80 \%$ ammonium sulphate was added to fat free fraction for ageing of precipitate for $12 \mathrm{~h}$, and formed precipitate was collected through Whatman filter paper and stored in tube already containing $20 \mathrm{mM}$ potassium phosphate buffer, $\mathrm{pH} 6.5$.

2.3. Purification. Precipitate was dialyzed and centrifuged at $10000 \mathrm{rpm}$ for $10 \mathrm{~min}$ maintaining temperature at $4^{\circ} \mathrm{C}$. Supernatant was collected and filtered through $0.2 \mu \mathrm{m}$ syringe filter and then the filtrate was applied directly to column Fast Performance Liquid Chromatography (FPLC) Sephadex G-75 column. The column and pump were washed with milli-Q water, which is purified and deionized by Millipore water purification system using $0.2 \mu \mathrm{m}$ filter at flow rate of $0.5 \mathrm{~mL} / \mathrm{min}$ and preequilibrated with $50 \mathrm{mM}$ potassium phosphate buffer, $\mathrm{pH}$ 6.5. The separating 5 fractions were collected and concentrated by speed back vacuum concentrator. The fraction P5 showed maximum antimicrobial activity, which is determined by disc diffusion method, applied to HPLC (Water, BioSuite C-18 column, $4.6 \mathrm{~mm} \times 250 \mathrm{~mm}$ ). Column and pump were washed with milli Q water HPLC grade at the flow rate of $0.8 \mathrm{~mL} / \mathrm{min}$ and then equilibrated with isopropanol HPLC grade at the flow adjusted to $0.8 \mathrm{~mL} / \mathrm{min}$ at wavelength of $280 \mathrm{~nm}$. Two fractions were separately collected through HPLC and further concentrated in speed back vacuum concentrator until the volume of sample reduced by one tenth of volume. The concentrated protein sample was tested for antimicrobial activity which is determined by disc diffusion method.

\subsection{Polyacrylamide Gel Electrophoresis (SDS-PAGE) of Pro-} tein. The purity test and further analysis of purified peptide Hispidalin were performed using standard tricine SDS-PAGE with slight modifications [27].

2.5. MALDI-TOF/MS Peptide Characterization. The purified Hispidalin was submitted to MALDI-TOF (Bruker Daltonics) for the amino acid composition and peptide fingerprint analysis. The peptide was digested with trypsin and spectra were collected in monoisotopic negative ion mode.

2.6. Antimicrobial Activity. The bacterial strains used were Escherichia coli, Pseudomonas aeruginosa, Bacillus cereus, Staphylococcus aureus, and Salmonella enterica and the fungal strains were Aspergillus flavus, Penicillium chrysogenum, Fusarium Solani, Colletotrichum gloeosporioides, and Curvularia geniculata. These bacterial and fungal strains were all obtained as clinical isolates from patients at the Microbiology Department, SMS Hospital Jaipur. Stock cultures were maintained at $4^{\circ} \mathrm{C}$ on slant of nutrient agar (NA) for bacteria and potato dextrose agar (PDA) for fungus, prior to their use. Antimicrobial activity of peptide sample was evaluated by the paper disc diffusion method [28]. Nutrient agar plate was prepared for bacteria and potato dextrose agar plate was prepared for fungus $40 \mu \mathrm{g} / \mathrm{mL}$ protein sample transferred to the $6 \mathrm{~mm}$ blank paper disc. Dried disc was placed on the plates previously inoculated with a bacterial suspension (concentration of $10^{6} \mathrm{cfu} / \mathrm{mL}$ ) and fungus. The incubation condition maintained at $35^{\circ} \mathrm{C}$ for $24 \mathrm{~h}$ for bacteria and 7 days for fungus. Plates were then examined for the presence of growth inhibition zones, and diameters were measured, if any. Ciprofloxacin disc for bacteria was used as positive control and griseofulvin disc for fungus and water as negative control. The experiment was done in triplicate.

2.7. Total Protein Estimation. Total protein estimation was performed as per the method of Bradford (1976). 
2.8. DPPH Free Radical Scavenging Activity Assay. The DPPH reagent was prepared by dissolving the $0.04 \mathrm{~g}$ DPPH to $95 \%$ of $100 \mathrm{~mL}$ methanol. Then the $2.95 \mathrm{~mL}$ of DPPH reagent was added to the $0.05 \mathrm{~mL}$ protein sample with varied concentrations $(5,10,15,20,25,30,35$, and $40 \mu \mathrm{g} / \mathrm{mL})$. Then, the absorbance of reaction mixture was measured at $517 \mathrm{~nm}$ using spectrophotometer (Varian Cary $100 \mathrm{UV}$ Visible). $\alpha$-Tocopherol $(1 \mathrm{mg} / \mathrm{mL})$ was used as standard and the DPPH without protein sample was used as control. Lower absorbance of the reaction mixture indicates higher free radical scavenging activity [29].

\subsection{Ferric Thiocyanate- (FTC-) Thiobarbituric Acid (TBA)} Method Based Lipid Peroxidation Determination. The standard method described by [30] was used with some modification. In brief, $40 \mu \mathrm{g} / \mathrm{mL}$ protein samples was mixed with $4 \mathrm{~mL}$ of ethanol (99.5\%). Then, the mixture added with $4.1 \mathrm{~mL}$ of $2.5 \%$ linolenic acid in $99.5 \%$ ethanol, $8.0 \mathrm{~mL}$ of $0.05 \mathrm{M}$ potassium phosphate buffer, $\mathrm{pH} 7.0$, and $3.9 \mathrm{~mL}$ of water was placed in a screw-capped vial and then placed in an oven at $40^{\circ} \mathrm{C}$ in the dark. Then, $0.1 \mathrm{~mL}$ of this solution was added to $9.7 \mathrm{~mL}$ of $75 \%$ ethanol and $0.01 \mathrm{~mL}$ of $30 \%$ ammonium thiocyanate. Further, $0.2 \mathrm{~mL}$ of $0.02 \mathrm{M}$ ferrous chloride in $3.5 \% \mathrm{HCl}$ was added to the mixture. At the end of the seven days, $2 \mathrm{~mL}$ of $20 \%$ tricholoacetic acid and $2 \mathrm{~mL}$ of $0.67 \%$ TBA were added to $1 \mathrm{~mL}$ of sample mixture prepared above. This mixture was then placed in boiling water bath at $100^{\circ} \mathrm{C}$ for 10 minutes. After cooling, it was centrifuged at $3000 \times \mathrm{rpm}$ for $20 \mathrm{~min}$ at normal temperature. Then the absorbance of supernatant at $532 \mathrm{~nm}$ using spectrophotometer (Varian Cary 100 , UV visible) was measured. The mixture without adding protein sample was used as control and $\alpha$-tocopherol was used as the standard.

\section{Results and Discussion}

In nature, abundant and diverse antimicrobial peptides are produced by several organisms including invertebrate, plant, animal, and bacterial species [2, 12, 19-21]. Their amino acid composition, amphipathicity, cationic charge, and size allow them to be attached to and inserted into membrane bilayers to form pores by "barrel-stave," "carpet," or "toroidal-pore" mechanisms $[2,6,12]$. Most of the antimicrobial peptides identified are cationic peptides with low molecular weight and exhibit hydrophobic properties $[2,6,12,21]$. Based on the three-dimensional structures of known peptides, antimicrobial peptides are generally classified into four major groups including alpha-helix, beta-sheet, loop, and extended peptides. It is believed that the amphipathic structure of antimicrobial peptides is essential to their antimicrobial activity $[6,10,12,31]$. This Hispidalin is quite different from the defensine, a major class of cationic antimicrobial peptide from plants. Their sizes vary from 12-50 amino acids and have molecular masses of less than 10000 [6,11, 12, 20, 32, 33]. Cationic peptides are amphipathic conveying that they have both a hydrophobic region that interacts with lipids and a positively charged hydrophilic region that interacts with water or negatively charged residues $[6,11,12,20,32,33]$.

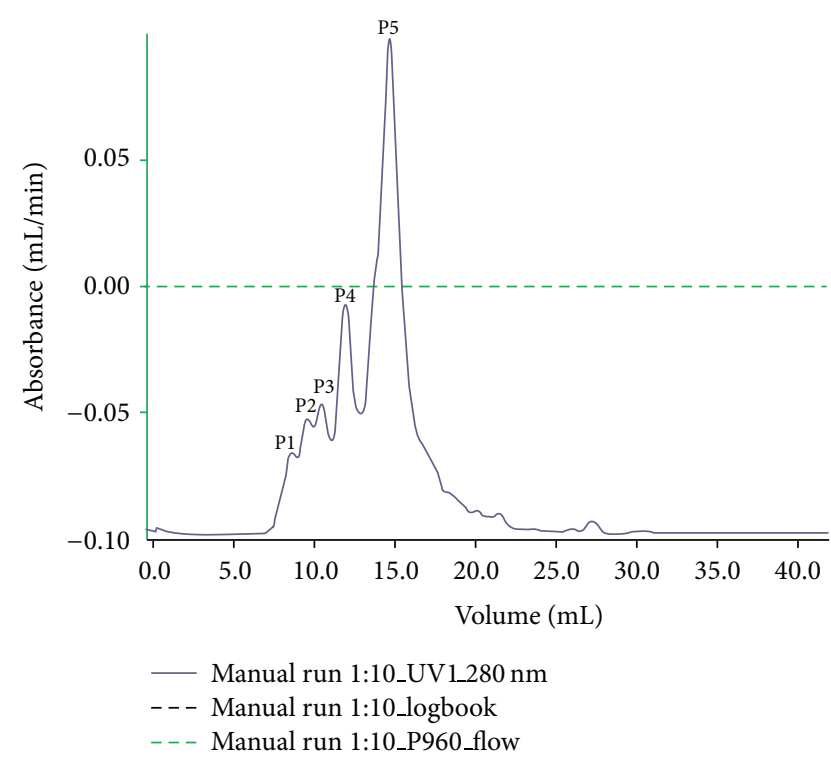

Figure 1: Sephadex G-75 Fast Performance Liquid Chromatography profile of antimicrobial peptide enriched fraction from $B$. hispida seeds. The monitoring of protein fraction was done at $280 \mathrm{~nm}$ wavelength and major peaks are represented as P1, P2, P3, P4, and P5.

This feature permits the peptides to intermingle well with membranes that are composed of amphipathic molecules, especially negatively charged bacterial membranes $[6,12]$. For the most part, animal cells tend to have membranes with no net charge so they are unaffected by cationic peptides $[6,12,20]$.

3.1. Extraction and Purification of Peptide from Seeds of B. hispida. Our initial effort was to extract and isolate pure peptide from seeds of $B$. hispida. The weight of fruit taken was $3800 \mathrm{~g}$ and the weight of seeds extracted from fruit was $500 \mathrm{~g}$. The weight of precipitate obtained from fraction after $80 \%$ ammonium sulphate precipitation was $38 \mathrm{~g}$. After precipitation, the precipitate was applied to Sephadex G-75 column, which yielded five peaks (Figure 1) and purification yields are presented in Table 2. Out of which the P5 had maximum biological activities including antimicrobial and antioxidant activities shown in Table 1 and Figures 3(a) and 3(b). P5 fraction was submitted to final purification by HPLC, which yielded two P1 and P2 peaks (Figure 2) out of which the P1 had maximum biological activities including antimicrobial and antioxidant activity. As zone of inhibition determined by disc diffusion against $E$. coli growth was found to be $29 \mathrm{~mm}$ for HPLC-P1 presented in Table 1 and Figure 4, this fraction HPLC-P1 also demonstrated maximum DPPH scavenging activity up to $76.83 \%$ and $72.3 \%$ lipid peroxidation inhibition shown in Table 1 . The fraction P1 was submitted to triacineSDS-PAGE analysis to resolve its molecular weight. Based on gel analysis, we observed a single $\sim 6.0 \mathrm{kDa}$ peptide band depicted by (Figure 3 ), suggested to be of bioactive peptide of interest. Here, obtained bioactive peptide purified from $B$. hispida is designated as Hispidalin name. 
TABLE 1: Antibacterial and antioxidant activity of FPLC and HPLC fractions.

\begin{tabular}{lccc}
\hline Fractions & $\begin{array}{c}\text { Zone diameter }(\mathrm{mm}) \text { of fractions } \\
\text { at } 40 \mu \mathrm{g} / \mathrm{mL} \text { concentration }\end{array}$ & $\begin{array}{c}\text { \% lipid peroxide inhibition by } \\
\text { fractions at } 40 \mu \mathrm{g} / \mathrm{mL} \text { concentration }\end{array}$ & $\begin{array}{c}\text { DPPH \% inhibition at } \\
40 \mu \mathrm{g} / \mathrm{mL} \text { concentration }\end{array}$ \\
\hline FPLC-P1 & - & $3.4 \pm 0.3$ & $17.8 \pm 1.0$ \\
FPLC-P2 & - & $6.5 \pm 0.6$ & $19.6 \pm 2.1$ \\
FPLC-P3 & - & $11.8 \pm 1.0$ & $12.1 \pm 1.1$ \\
FPLC-P4 & 9 & $31.0 \pm 2.7$ & $18.9 \pm 1.2$ \\
FPLC-P5 & 15 & $53.9 \pm 6.0$ & $64.1 \pm 5.4$ \\
HPLC-P1 & 29 & $72.3 \pm 6.82$ & $76.83 \pm 6.93$ \\
HPLC-P2 & 12 & $54.8 \pm 7.83$ & $48.93 \pm 5.53$ \\
Standard & (Ciprofloxacin) 22 & $(\alpha$-Tocopherol) 64.76 & $(\alpha$-Tocopherol) 77.7 \\
\hline
\end{tabular}

Data are represented as means \pm SD.

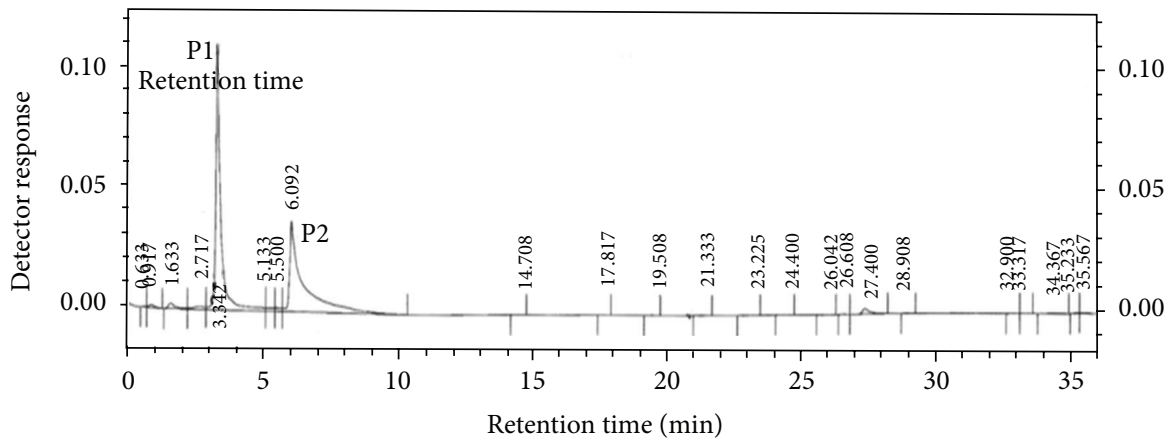

UV-VIS $(280 \mathrm{~nm})$

Pk\# Name

FIGURE 2: Reverse phase chromatography profile of the antimicrobial peptide enriched fraction P5 obtained from the FPLC purification presented in Figure 1. The elution profile was monitored at $280 \mathrm{~nm}$ UV-VIS detector. We identified two peaks P1 and P2 obtained from HPLC.

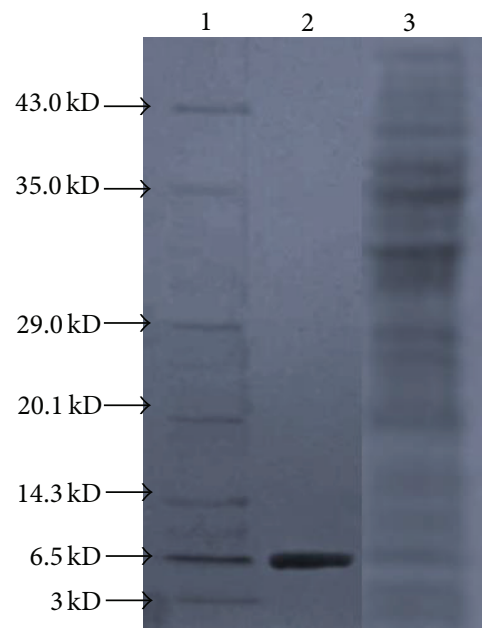

Figure 3: Tricine SDS-PAGE profile of Hispidalin peptide from $B$. hispida. Lane 1: low molecular weight protein marker, Lane 2: ten microgram of purified Hispidalin was loaded, and Lane 3: twenty microgram of Crude B. hispida seed protein was loaded.

3.2. MALDI-TO-TOF MS/MS Characterization of Hispidalin Peptide from B. hispida Seeds. The MALDI-TOF-TOF MS/MS analysis of Hispidalin peptide was done to confirm the molecular weight and amino acid sequence analysis
TABle 2: Purification table of Hispidalin showing percentage yield during FPLC and HPLC purification.

\begin{tabular}{lcc}
\hline Name of fraction & $\begin{array}{c}\text { Quantity of protein } \\
\text { precipitate }\end{array}$ & $\begin{array}{c}\text { Percentage } \\
\text { yield }\end{array}$ \\
\hline $\begin{array}{l}\text { Ammonium sulphate } \\
\text { precipitate }\end{array}$ & $\begin{array}{c}38 \text { g out of 500 g dry } \\
\text { seeds }\end{array}$ & $7.6 \%$ \\
FPLC-P1 & 1.46 & $2.35 \%$ \\
FPLC-P2 & 1.94 & $9.7 \%$ \\
FPLC-P3 & 1.83 & $3.8 \%$ \\
FPLC-P4 & 2.23 & $11.75 \%$ \\
FPLC-P5 & 3.93 & $16.75 \%$ \\
HPLC-P1 & 0.56 & $56.73 \%$ \\
HPLC-P2 & 0.41 & $34.63 \%$ \\
\hline
\end{tabular}

as determined by the Tricine-SDS-PAGE. In Figure 5(a), MALDI-TOF MS spectra of trypsinized Hispidalin is provided and it showed four different small peptides with molecular mass of peptide 1 (1075.56), peptide 2 (1449.7121), peptide 3 (1500.73), and peptide 4 (1728.83). We also performed the MS/MS analysis of the obtained peaks after trypsinization of the Hispidalin. The TOF-MS-MS spectra of each trypsinized smaller peptide consisting of a series of $y$ and $b$ ions and several ions are illustrated in Figures 5(a), 5(b), and 5(c). The 


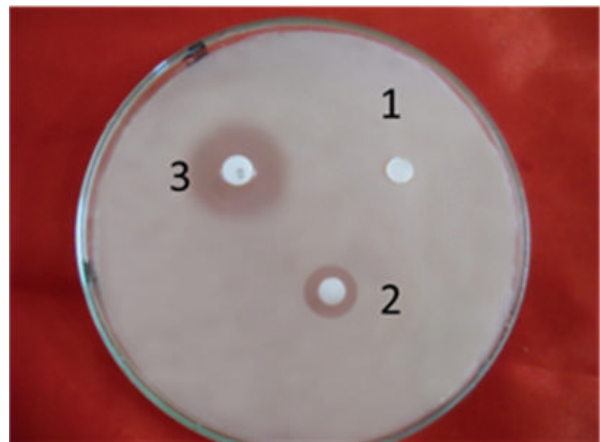

(a)

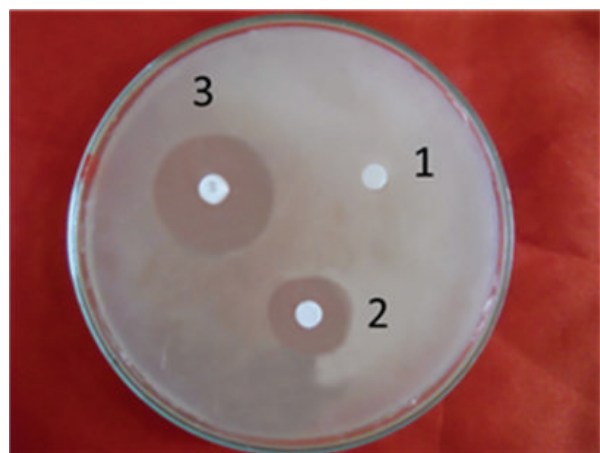

(c)

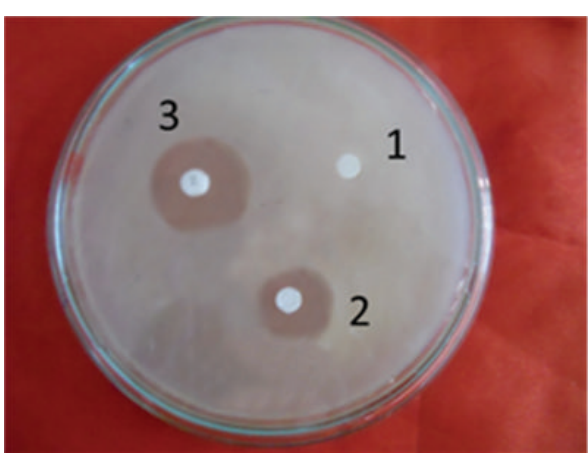

(b)

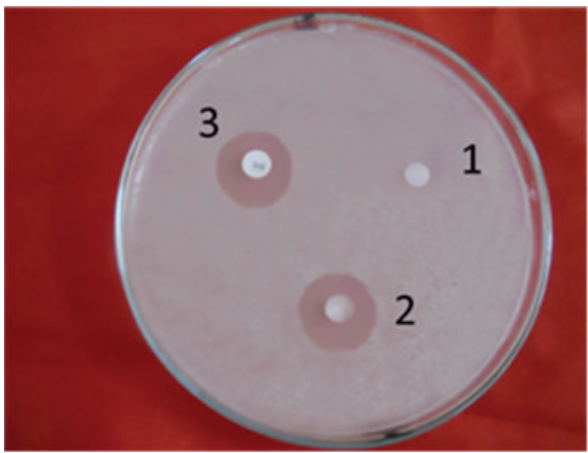

(d)

FIgURE 4: Antibacterial activity of bioactivity guided fraction from B. hispida against E. coli (a), fraction P4 from FPLC, (b) fraction P5 from FPLC, (c) fraction P1 from HPLC, and (d) fraction P2 from HPLC. 1: only water, 2: peptide, and 3: ciprofloxacin.

MS-digest pattern of Hispidalin peptide amino acid sequence using the UCSF protein prospector software is also presented in Figure 5(d). The molecular weight of the peptide was determined to be 5.7 Kodak, with 49 amino acid sequences as follows: SDYLNNNPLFPRYDIGNVELSTAYRSFANQKAPGRLNQNWALTADYTYR. The amino acid sequence alignment was performed against the NCBI database and APD. During MALDI-TOF MS/MS analysis, the peptide generated four trypsin digested fragments having MW of peptide 1 (1075.56), peptide 2 (1449.7121), peptide 3 (1500.73), and peptide 4 (1728.83). We summed up MW of four peptides, it is around $5.7 \mathrm{KDa}$, which confirmed the Tricine-SDSPAGE data showing 6.0 KD in size depicted in Figures 5(a), 5(b), 5(c), and 5(d). The low similarity of the amino acid sequences indicated that the Hispidalin peptide is the first novel reported peptide from $B$. hispida seeds. This protein has 49 amino acid residues having both hydrophobic and hydrophilic residues. After analyzing the peptide sequence using mass analyzer, it indicates that this is cationic peptide with one net positive and having isoelectric $\mathrm{pH}-8.1$. On the basis of one excess positively charged amino acid, this peptide has +1 net negative charge, which is in agreement that basic peptides has been reported to have +1 to +7 negative charge on their extended backbone. Important information about Hispidalin is that it does not contain any sulphur containing amino acid. Therefore, results strongly suggest that Hispidalin is without any folded structure and may exist in their native extended conformations. The amphiphilic nature of Hispidalin strengthens its candidacy to be a potent antimicrobial agent. Matrix-assisted laser desorption/ionization (MALDI) time-of-flight (TOF) mass spectrometry (MS) is now routinely used in many laboratories for the rapid and sensitive identification of proteins by peptide mass fingerprinting (PMF). When we submitted peptide sequence to NCBI database, it only matched hypothetical and uncharacterized protein of Molecular mass $23 \mathrm{KDa}$ from Aeromonas veronii having maximum identity $66 \%$ [34]. It emphasizes our findings that this antimicrobial cationic peptide is new and there is no report from any organisms. To the best of our knowledge, this is the first information that basic low molecular weight peptide Hispidalin from $B$. hispida seeds demonstrated promising antimicrobial and antioxidant activity. We strongly believe that Hispidalin with 49 amino acid amino acid residue is a basic peptide with one net negative charge isolated from the seeds of $B$. hispida. At the same time, Hispidalin showed no sequence homology to any known plant protein, except with the hypothetical and uncharacterized protein from the bacteria. All cationic peptides are encoded in the form of bigger precursors with signal sequences that are later on modified by cleavage or group addition reactions such as glycosylation or halogenation $[6,12,20]$.

3.3. Antimicrobial Activity of Hispidalin Peptide. We have assessed and demonstrated the potent antibacterial and 


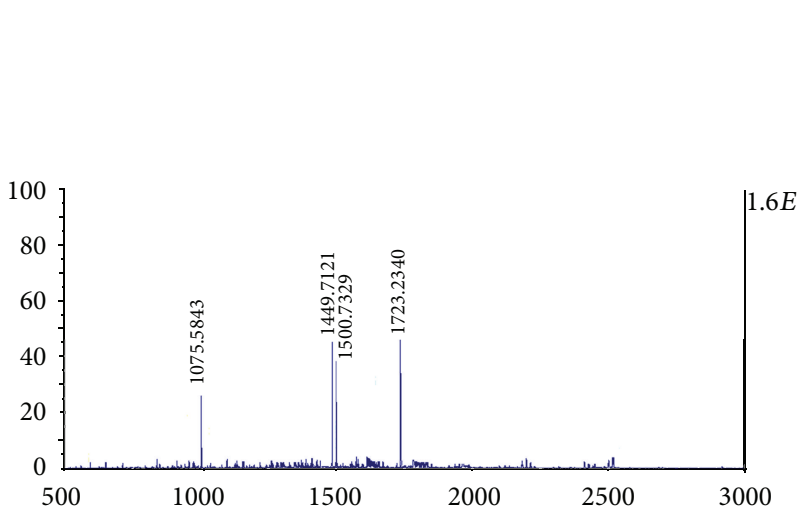

(a)

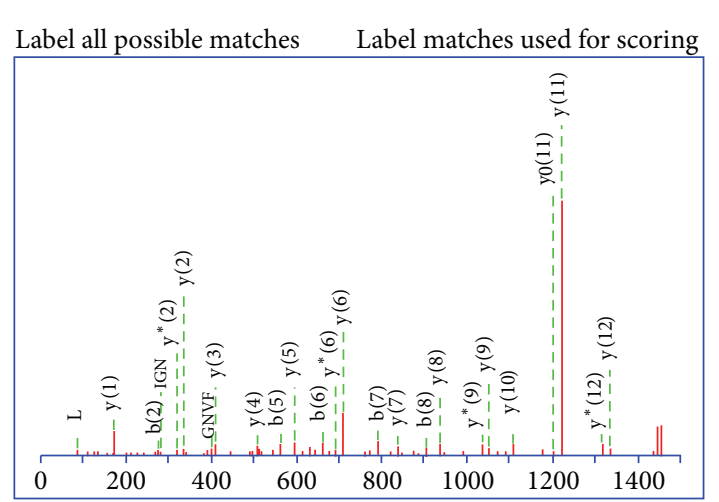

(c)

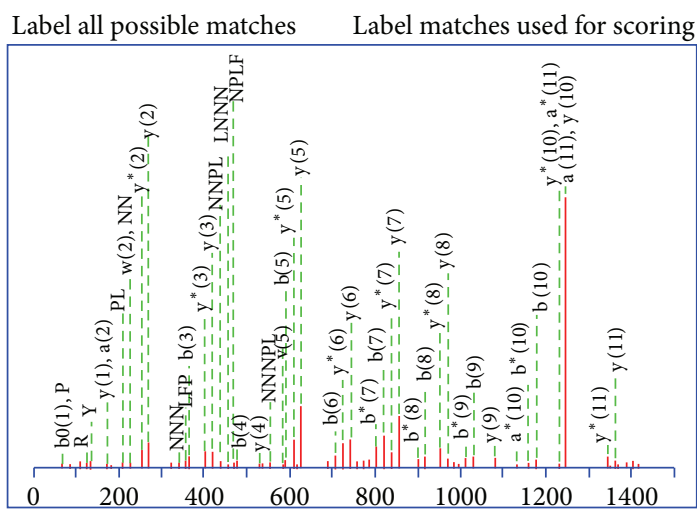

(b)

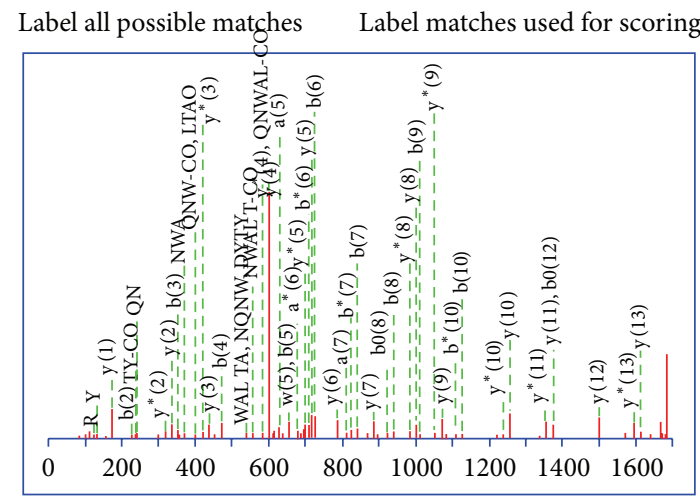

(d)

MS-digest search results

(+) parameters

Index number: 1

pI of protein: 8.1

Protein MW: 5700

Amino acid composition: A5 D3 E1 F2 G2 I1 K1 L5 N7 P3 Q2 R4 S3 T3 VI W1 Y5

1 SDYLNNNPLF PRYDIGNVEL STAYRSFANQ KAPGRLNQNW ALTADYTYR_

\begin{tabular}{|c|c|c|c|c|c|c|}
\hline Number & $\begin{array}{l}\mathrm{m} / \mathrm{z} \\
(\mathrm{mi})\end{array}$ & $\begin{array}{l}\mathrm{m} / \mathrm{z} \\
\text { (av) }\end{array}$ & Modifications start & End & $\begin{array}{l}\text { Missed } \\
\text { cleavages }\end{array}$ & Sequence \\
\hline 1 & 1075.5643 & 1076.2074 & 26 & 35 & 1 & (R) SFANQKAPGR(L) \\
\hline 1 & 1449.7121 & 1450.6036 & 1 & 12 & 0 & (一) SDYLNNNPLFPR(Y) \\
\hline 1 & 1491.7227 & 1492.6411 1Acetyl & 1 & 12 & 0 & (一) SDYLNNNPLFPR(Y) \\
\hline 1 & 1500.7329 & 1501.6459 & 13 & 25 & 0 & (R) YDIGNVELSTAYR(S) \\
\hline 1 & 1728.8340 & 1729.9012 & 36 & 49 & 0 & (R) LNQNWALTADYTYR $(-)$ \\
\hline 1 & 2110.0465 & 2111.3389 & 32 & 49 & 1 & (K) APGRLNQNWALTADYTYR(-) \\
\hline 1 & 2176.0669 & 2177.3930 & 13 & 31 & 1 & (R) YDIGNVELSTAYRSFANQK(A) \\
\hline 1 & 2931.4272 & 2933.2268 & 1 & 25 & 1 & (一) SDYLNNNPLFPRYDIGNVELSTAYR(S) \\
\hline 1 & 2973.4377 & 2975.2643 lAcetyl & 1 & 25 & 1 & (-) SDYLNNNPLFPRYDIGNVELSTAYR(S) \\
\hline
\end{tabular}

(e)

FIGURE 5: (a) MALDI-TOF MS spectra of trypsinized Hispidalin peptide. (b) MS/MS fragmentation of first peptide 1 from Hispidalin SDYLNNNPLFPR using MALDI-TOF. (c) MS/MS fragmentation of Peptide 2 from Hispidalin YDIGNVELSTAYR using MALDI-TOF. (d) MS/MS fragmentation of peptide 3 from Hispidalin LNQNWALTADYTYR using MALDI-TOF. (e) MS-digest pattern of Hispidalin peptide amino acid sequence using the UCSF protein prospector software. 


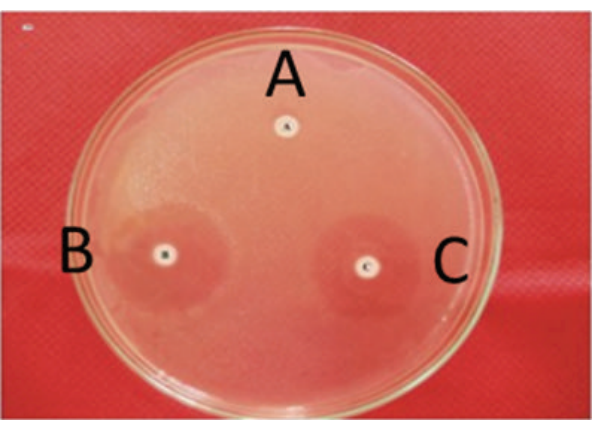

(a)

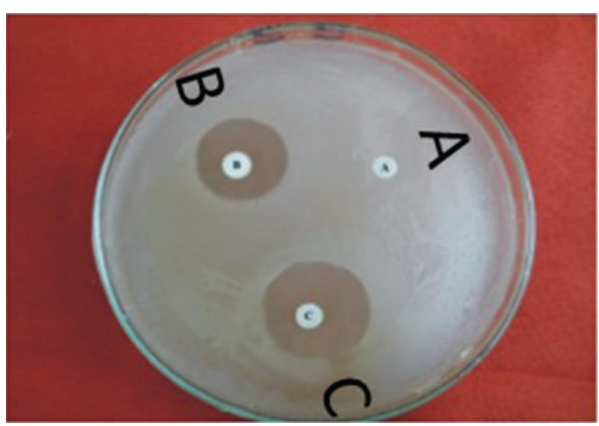

(c)

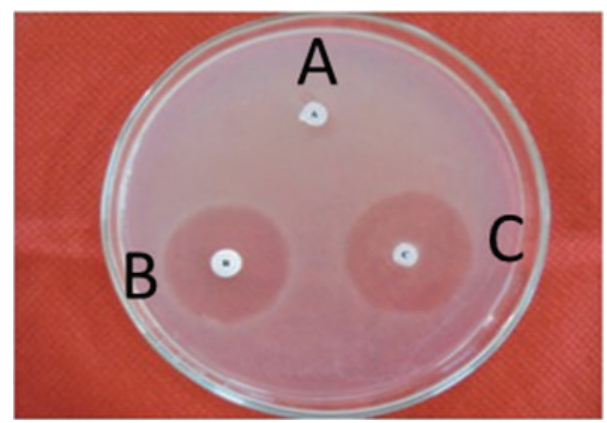

(b)

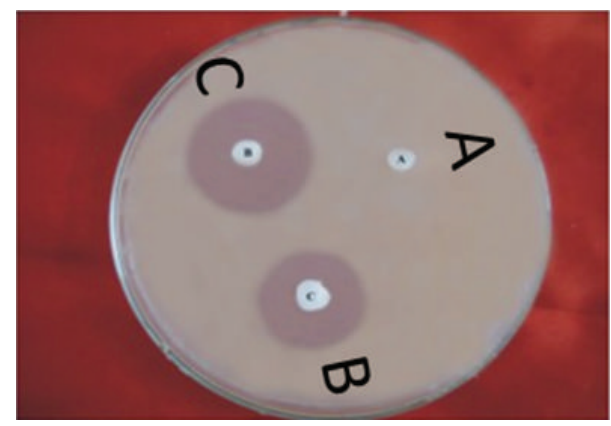

(d)

FIgURE 6: Antibacterial activity of Hispidalin $(40 \mu \mathrm{g} / \mathrm{mL})$ peptide against E. coli (a), II- S. enterica (b), P. aeruginosa (c), and S. aureus (d). (A) For negative control (water), (B) positive control (ciprofloxacin), and (C) Hispidalin disc.

TABLE 3: Antibacterial activity of Hispidalin $(40 \mu \mathrm{g} / \mathrm{mL})$ peptide using disc diffusion activity.

\begin{tabular}{lcc}
\hline Bacterial strain & $\begin{array}{c}\text { Zone diameter }(\mathrm{mm}) \\
\text { of peptide }\end{array}$ & $\begin{array}{c}\text { Zone diameter }(\mathrm{mm}) \\
\text { of ciprofloxacin }\end{array}$ \\
\hline E. coli & $26 \pm 2$ & $29 \pm 1.5$ \\
P. aeruginosa & $24 \pm 1.5$ & $21 \pm 2$ \\
B. cereus & - & - \\
S. enterica & $29 \pm 1$ & $28 \pm 1.5$ \\
S. aureus & $25 \pm 2$ & $29 \pm 2$ \\
\hline
\end{tabular}

Data are represented as means of triplicate \pm SD.

antifungal activity of Hispidalin against selected bacterial and fungal strain.

3.4. Antibacterial Activity of Hispidalin. Antibacterial activity (assessed in terms of inhibition zone and activity index) of peptide by disc diffusion method tested against selected microorganisms were recorded and presented in (Figure 6 and Table 3). In the present study, in vitro antibacterial activity of Hispidalin have shown maximum zone of inhibition $29 \mathrm{~mm}$ against $S$. enterica and minimum $24 \mathrm{~mm}$ against $P$. aeruginosa bacterial strain. In this antibacterial assay, ciprofloxacin is taken as standard antibacterial agents. Antibacterial activity was also assessed in terms of MIC and $\mathrm{MBC}$ index of Hispidalin against selected bacterial strain and data are presented in Table 5. In the present study, Hispidalin peptide showed minimum MIC $(80 \mu \mathrm{g} / \mathrm{mL})$ and MBC $(100 \mu \mathrm{g} / \mathrm{mL})$ against $S$. enterica bacterial strain.
The inhibitory effect of Hispidalin against selected bacterial organisms is shown in Table 3. The Hispidalin exhibited significant antibacterial activity at $40 \mu \mathrm{g} / \mathrm{mL}$ showing inhibition zone ranging from 18 to $29 \mathrm{~mm}$ in Figure 6. The tested Hispidalin peptide showed very convincing comparable antibacterial activity on most of selected gram-negative as well as gram-positive bacteria except $B$. cereus strain in comparison to standard antibacterial agent ciprofloxacin. This observation was defended based on earlier reports that Bacillus sp. strain has accumulated several plant origin peptides due to gene transfer between plant and bacteria. Due to this reason, Bacillus sp. has its endogenous peptide similar to plant peptide and adapted to the inhibitory actions of reported Hispidalin plant antimicrobial peptide [35]. Plant peptides carry out indispensable roles in plant survival, being directly involved in defense mechanisms against multiple pathogens. Amongst several classes of plant peptides like cyclotides, defensins, glycine-rich proteins, and other unusual classes, our identified Hispidalin falls under unknown unusual class of family, basic in nature with extended linear conformation without any disulfide linkage due to absence of any cysteine residue. In several reported antimicrobial peptides from seeds, where there are no similar structures, the main explanation of antimicrobial activity relies on the amphipathic surface of protein. Earlier studies have demonstrated that, although there are several antimicrobial peptides described, most of them inhibit only phytopathogens or only human pathogens $[4,8,9]$. Therefore, analyzing the antimicrobial peptides from plant sources described earlier in the literature $[5,12,20,31,32,36,37]$, we can conclude that Hispidalin is the first peptide from 

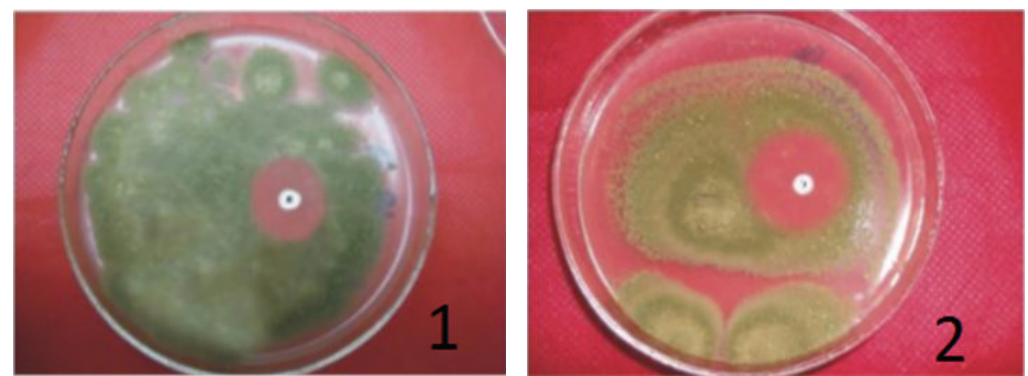

(a)
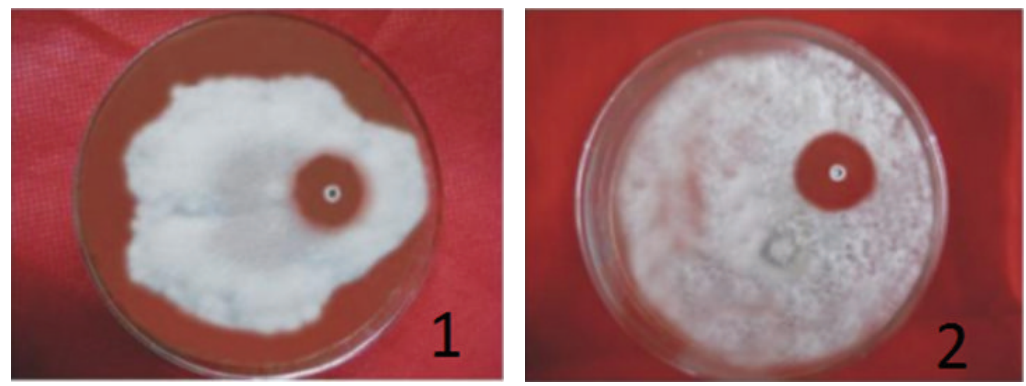

(b)
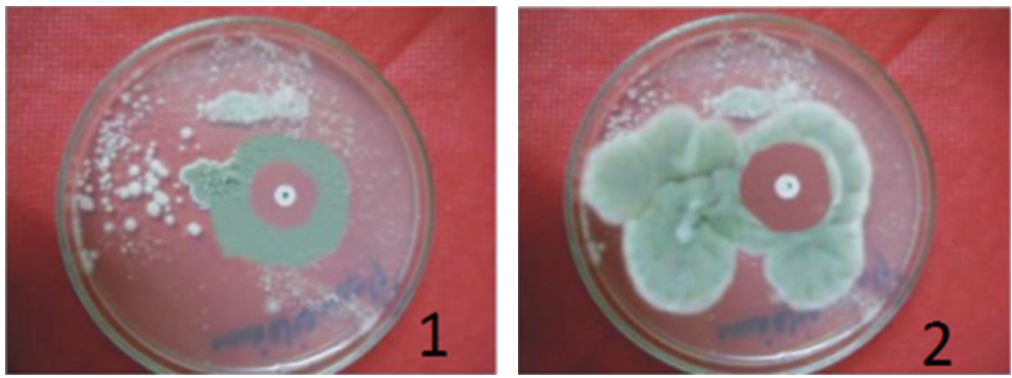

(c)
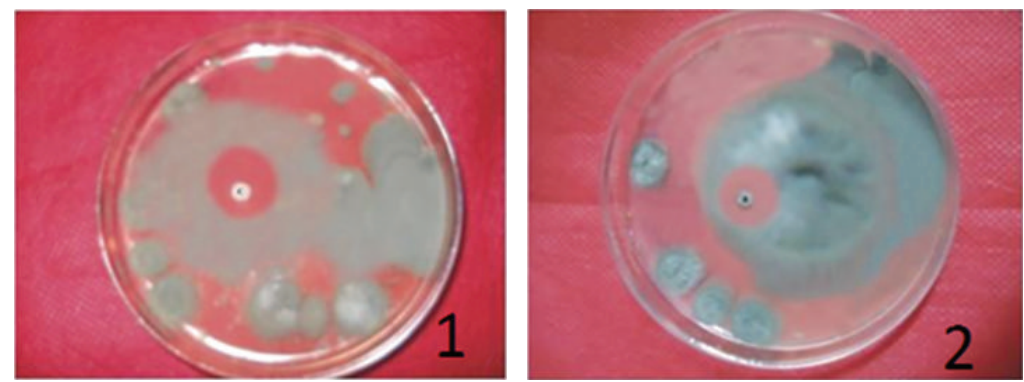

(d)

Figure 7: Inhibitory activity of Hispidalin $(40 \mu \mathrm{g} / \mathrm{mL})$ on the growth of A. flavus (a), F. solani (b), P. chrysogenum (c), C. geniculata (d). by paper disk diffusion assay. Here, 1 is for peptide disc and 2 is for positive control griseofulvin antifungal agent.

B. hispida to present antibacterial activity against human pathogenic bacterium. The Hispidalin peptide sequence shows no homology to any previously described proteins and these findings are strengthened by the recent report from Stellaria media seeds showing antimicrobial activity without homology with previously known antimicrobial peptides from plant sources [5].

3.5. Antifungal Activity of Hispidalin. The antifungal potency of the Hispidalin was studied on five different plant pathogenic fungi and compared to that of antifungal proteins griseofulvin in Table 4 . The concentration of Hispidalin at $40 \mu \mathrm{g} / \mathrm{mL}$ demonstrated significant zone of fungal hyphae growth inhibition ranging from minimum $18 \mathrm{~mm}$ (C. geniculata) to maximum $21 \mathrm{~mm}$ (A. flavus) (Figure 7 and Table 4 ). The comparative analysis of growth zone inhibition indicated that Hispidalin showed differential antifungal potential against different fungal strain; moreover, antifungal potency was highly comparable with well-known antifungal agent griseofulvin. Antifungal activity also assessed in 
TABLE 4: Antifungal activity of Hispidalin $(40 \mu \mathrm{g} / \mathrm{mL})$ peptide using disc diffusion method.

\begin{tabular}{lcc}
\hline Fungal strain & $\begin{array}{c}\text { Zone diameter }(\mathrm{mm}) \\
\text { of peptide }\end{array}$ & $\begin{array}{c}\text { Zone diameter }(\mathrm{mm}) \\
\text { of griseofulvin }\end{array}$ \\
\hline A. flavus & $21 \pm 1.5$ & $30 \pm 1$ \\
F. solani & $21 \pm 2$ & $22 \pm 1.5$ \\
C. geniculata & $18 \pm 2$ & $22 \pm 2$ \\
C. gloeosporioides & - & - \\
P. chrysogenum & $20 \pm 1.5$ & $26 \pm 1.5$ \\
\hline
\end{tabular}

Data are represented as means of triplicate \pm SD.

terms of MIC and MFC index of Hispidalin tested against selected fungal strain is presented in Table 5. In terms of antifungal potential, Hispidalin demonstrated the least MIC $(120 \mu \mathrm{g} / \mathrm{mL})$ and MFC $(160 \mu \mathrm{g} / \mathrm{mL})$ against $A$. flavus fungal strain. The data clearly demonstrated significant antifungal potential of Hispidalin against most of selected plant and human pathogenic fungi except C. gloeosporioides fungal strain in comparison to standard antifungal agent griseofulvin. These fungal species have previously been shown to be responsive to a variety of antifungal proteins $[11,27,29,32$, 35]. The inability of Hispidalin to act against C. gloeosporioides supports the reported claim that this fungal strain as an endophytic fungus has acquired parallel antifungal protein/peptide from the host plant [36]. The MICs value of Hispidalin against four fungal species ranged between 120 and $200 \mu \mathrm{g} / \mathrm{mL}$, which is highly comparable with those of other reported antifungal peptides such as Udenya Africana seeds peptides (MIC $=50-200 \mu \mathrm{g} / \mathrm{mL}$ ) [24], Lunatasin from Phaseolus lunatus (MIC and MFC $=50-200 \mu \mathrm{g} / \mathrm{mL}$ ), and castamollin from Chinese chestnuts (IC50 $=2.5 \mu \mathrm{M})$ [23]. A further appraisal with reported data on the activity of other antifungal proteins/peptides reveals that Hispidalin is among the most potent antifungal proteins known previously.

\subsection{Determination of Free Radical Scavenging Activity Using} DPPH Assay. As shown in Figure 8, the peptide showed a concentration dependent DPPH radical-scavenging activity and $40 \mu \mathrm{g} / \mathrm{mL}$ of peptide showed maximum inhibition. DPPH radical-scavenging activity of the purified peptide was found to be $70.8 \%$ at $40 \mu \mathrm{g} / \mathrm{mL}$. The protein exhibited a statistically similar DPPH radical-scavenging activity when compared with standard antioxidant $\alpha$-tocopherol which showed $74.9 \%$ scavenging of radicals at $40 \mu \mathrm{g} / \mathrm{mL}$ concentration. The $\mathrm{IC}_{50}$ values of peptide and $\alpha$-tocopherol are $14.84 \mu \mathrm{g} / \mathrm{mL}$ and $14.15 \mu \mathrm{g} / \mathrm{mL}$, respectively. DPPH radicals, a stable radical used to evaluate the antioxidant activity of plant and microbial extracts $[23,24]$. The obtained antioxidant activity presented in terms of free radical-scavenging activity is in agreement with previously reported protein/peptide from different plant sources [23-26]. The analysis of Hispidalin reveals the presence of three serine, three threonine, and five tyrosine amino acids containing hydroxyl group. Our findings support the previous claim that hydroxyl groups are responsible for free radical-scavenging activity of earlier reported peptides and flavonoids [24-26]. The amino acid

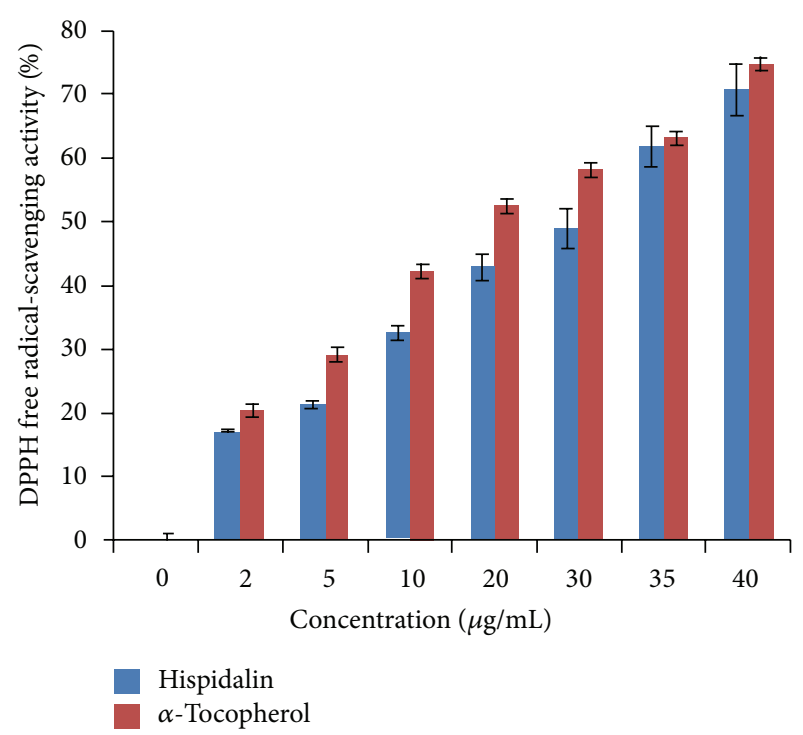

FIGURE 8: DPPH free radical scavenging activity of Hispidalin (0$40 \mu \mathrm{g} / \mathrm{mL})$. Data are the mean of triplicates \pm SD.

analysis of Hispidalin also confirmed the hydrophilic nature and supports earlier suggestion that hydrophilic nature of peptide is contributing potent antioxidant activity against soluble free radicals like DPPH.

\subsection{Lipid Peroxidation Inhibition Potential of Hispidalin Using} Ferric Thiocyanate (FTC) TBA and TBA Method. FTC-TBA method measures the amount of peroxide value and products at the end of lipid peroxidation, where ferric ion was formed upon reaction of peroxide with ferrous chloride. The ferric ion will then unite with ammonium thiocyanate producing ferric thiocyanate, a red-colored substance. The TBA test combined with FTC is used to measure the secondary product of oxidation such as aldehyde and ketones [23, 24]. The data presented in Figures 9(a) and 9(b) shows the TBA mediated estimation of lipid peroxidation product MDA in the presence of Hispidalin and $\alpha$-tocopherol at the seventh day of storage. The percentage of lipid peroxidation inhibition due to the peptide antioxidant activity was $69.5 \%$, which is convincingly similar to $\alpha$-tocopherol, where the percentage of inhibition was $71.5 \%$. This result was in consonance with previous study [24-26] that among the different lipid peroxidation products used for the antioxidant assays, malonaldehyde MDA has been widely considered as a marker for the evaluation of antioxidant capacity of several chemicals and peptides. In several reports, lipid peroxidation inhibition due to antioxidant peptide is being measured by TBA-FTC method. Lipid is the principal component of cell membranes. A cell is seriously damaged by the lipid peroxidation. Hence, the inhibition of linoleic acid peroxidation is an important guide of antioxidant properties. The observed lipid peroxidation inhibition by Hispidalin may be attributed due to its metal ion chelating activity. The findings suggest that presence of hydroxyl group containing amino acids in Hispidalin may help in chelating ferrous ion leading to 
TABLE 5: MIC and MBC/MFC of Hispidalin peptide.

\begin{tabular}{|c|c|c|c|c|}
\hline \multirow{2}{*}{ Bacterial strain } & \multicolumn{2}{|c|}{$\operatorname{MIC}(\mu \mathrm{g} / \mathrm{mL})$} & \multicolumn{2}{|c|}{$\mathrm{MBC}(\mu \mathrm{g} / \mathrm{mL})$} \\
\hline & Hispidalin & Ciprofloxacin & Hispidalin & Ciprofloxacin \\
\hline E. Coli & 100 & 30 & 120 & 40 \\
\hline P. aeruginosa & 120 & 100 & 120 & 120 \\
\hline B. cereus & - & - & - & \\
\hline S. enterica & 80 & 40 & 100 & 60 \\
\hline S. aureus & 100 & 50 & 120 & 60 \\
\hline \multirow{2}{*}{ Fungal strain } & \multicolumn{2}{|c|}{$\operatorname{MIC}(\mu \mathrm{g} / \mathrm{mL})$} & \multicolumn{2}{|c|}{$\operatorname{MFC}(\mu \mathrm{g} / \mathrm{mL})$} \\
\hline & Hispidalin & Griseofulvin & Hispidalin & Griseofulvin \\
\hline A. flavus & 120 & 100 & 160 & 80 \\
\hline F. solani & 130 & 120 & 180 & 60 \\
\hline C. geniculata & 200 & 180 & 220 & 160 \\
\hline C. gloeosporioides & - & - & - & - \\
\hline P. chrysogenum & 180 & 100 & 160 & 80 \\
\hline
\end{tabular}

${ }^{*}$ Mean of the MICs from three independent experiments. Hispidalin applied on the nutrient agar plates containing listed bacterial strains.

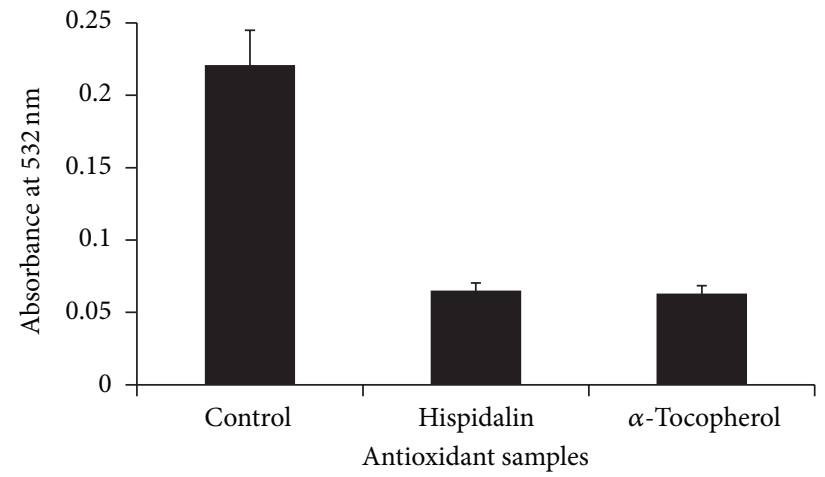

(a)

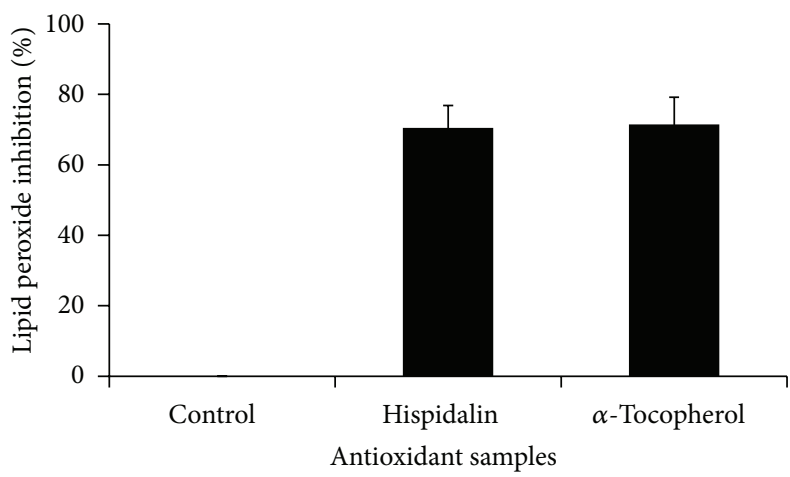

(b)

Figure 9: Antioxidant activity of Hispidalin $(40 \mu \mathrm{g} / \mathrm{mL})$ in terms of lipid peroxidation. (a) Absorbance at $532 \mathrm{~nm}$. (b) Percentage inhibition of lipid peroxide production. Data are the mean of triplicates \pm SD.

less lipid peroxidation products like aldehydes and ketones. In recent years, there are attention on the importance of bioactive peptide endowed with antioxidant activity and their significance in the pharmaceutical and therapeutic industry considerably promising substitute for the synthetic peptides. Based on the hydrophilic nature of Hispidalin and its ability to inhibit lipid peroxidation strengthen the earlier claim of lipid peroxidation ability of hydrophilic antioxidants.

\section{Conclusion}

In conclusion, we report purification of novel cationic antimicrobial and antioxidant Hispidalin peptide from $B$. hispida seeds. This peptide belongs to extended peptide conformation of plant AMP families. The peptides are active against human and plant pathogenic bacteria and fungi. The identification of this peptide holds good promise in the therapeutic and plant protection industry.

\section{Conflict of Interests}

The authors declare that there is no conflict of interests regarding the publication of this paper.

\section{Acknowledgment}

The authors would like to acknowledge the Chancellor, Jaipur National University, Jaipur, India for providing necessary resources and facility to carry out research work.

\section{References}

[1] B. Hernandez-Ledesma, C. C. Hsieh, and B. O. de Lumen, "Chemopreventive properties of peptide lunasin: a review," Protein and Peptide Letters, vol. 20, pp. 424-432, 2005.

[2] E. de Souza Cândido, M. H. E. S. Cardoso, D. A. Sousa et al., "The use of versatile plant antimicrobial peptides in agribusiness and human health," Peptides, vol. 55, pp. 65-78, 2014.

[3] C. Avitabile, R. Capparelli, M. M. Rigano et al., "Antimicrobial peptides from plants: stabilization of the $\gamma$ core of a tomato defensin by intramolecular disulfide bond," Journal of Peptide Science, vol. 13, no. 4, pp. 240-245, 2013.

[4] M. Pushpanathan, P. Gunasekaran, and J. Rajendhran, "Antimicrobial peptides: versatile biological properties," International Jounral of Peptides, vol. 2013, Article ID 675391, 15 pages, 2013. 
[5] A. A. Slavokhotova, E. A. Rogozhin, A. K. Musolyamov et al., "Novel antifungal $\alpha$-hairpinin peptide from Stellaria media seeds: structure, biosynthesis, gene structure and evolution," Plant Molecular Biology, vol. 84, no. 1-2, pp. 189-202, 2014.

[6] J. R. Soares, A. de Oliveira Carvalho, I. S. dos Santos et al., "Antimicrobial peptides from Adenanthera pavonina L. seeds: characterization and antifungal activity," Protein and Peptide Letters, vol. 19, no. 5, pp. 520-529, 2012.

[7] G. B. Dias, V. M. Gomes, U. Z. Pereira et al., "Isolation, characterization and antifungal activity of proteinase inhibitors from Capsicum chinense Jacq. seeds," The Protein Journal, vol. 32, no. 1, pp. 15-26, 2013.

[8] M. L. Gee, M. Burton, A. Grevis-James et al., "Imaging the action of antimicrobial peptides on living bacterial cells," Scientific Reports, vol. 3, article 1557, 2013.

[9] A. T. Girgih, C. C. Udenigwe, and R. E. Aluko, "Reversephase HPLC separation of hemp seed (Cannabis sativa L.) protein hydrolysate produced peptide fractions with enhanced antioxidant capacity," Plant Foods for Human Nutrition, vol. 68, no. 1, pp. 39-46, 2013.

[10] Y. N. Tan, M. K. Ayob, and W. A. W. Yaacob, "Purification and characterisation of antibacterial peptide-containing compound derived from palm kernel cake," Food Chemistry, vol. 136, no. 1, pp. 279-284, 2013.

[11] U. Zottich, M. Da Cunha, A. O. Carvalho et al., "An antifungal peptide from Coffea canephora seeds with sequence homology to glycine-rich proteins exerts membrane permeabilization and nuclear localization in fungi," Biochimica et Biophysica ActaGeneral Subjects, vol. 1830, no. 6, pp. 3509-3516, 2013.

[12] M. Zasloff, "Antimicrobial peptides of multicellular organisms," Nature, vol. 415, no. 6870, pp. 389-395, 2002.

[13] O. L. Franco, "Peptide promiscuity: an evolutionary concept for plant defense," FEBS Letters, vol. 585, no. 7, pp. 995-1000, 2011.

[14] M. A. Rachchh and S. M. Jain, "Gastroprotective effect of Benincasa hispida fruit extract," Indian Journal of Pharmacology, vol. 40, no. 6, pp. 271-275, 2008.

[15] D. Dhingra and P. Joshi, "Antidepressant-like activity of Benincasa hispida fruits in mice: possible involvement of monoaminergic and GABAergic systems," Journal of Pharmacology and Pharmacotherapeutics, vol. 3, pp. 60-62, 2012.

[16] Z. L. Qadrie, N. T. Hawisa, M. W. A. Khan, M. Samuel, and R. Anandan, "Antinociceptive and anti-pyretic activity of Benincasa hispida (Thunb.) Cogn. in Wistar albino rats," Pakistan Journal of Pharmaceutical Sciences, vol. 22, no. 3, pp. 287-290, 2009.

[17] S. Girdhar, M. M. Wanjari, S. K. Prajapati, and A. Girdhar, "Evaluation of anti-compulsive effect of methanolic extract of Benincasa hispida Cogn. fruit in mice," Acta Poloniae Pharmaceutica-Drug Research, vol. 67, no. 4, pp. 417-421, 2010.

[18] D. Natarajan, R. J. Lavarasan, S. C. Babu, M. A. Refai, and L. H. Ansari, "Antimicrobial studies on methanol extract of Benincasa hispida cogn., fruit," Ancient Science of Life, vol. 22, no. 3, pp. 98100, 2003.

[19] T. Nakatsuji and R. L. Gallo, "Antimicrobial peptides: old molecules with new ideas," Journal of Investigative Dermatology, vol. 132, no. 3, pp. 887-895, 2012.

[20] P. Wang, J. K. Bang, H. J. Kim, J. K. Kim, Y. Kim, and S. Y. Shin, "Antimicrobial specificity and mechanism of action of disulfide-removed linear analogs of the plant-derived Cys-rich antimicrobial peptide Ib-AMP1," Peptides, vol. 30, no. 12, pp. 2144-2149, 2009.

[21] L. Padovan, M. Scocchi, and A. Tossi, "Structural aspects of plant antimicrobial peptides," Current Protein and Peptide Science, vol. 11, no. 3, pp. 210-219, 2010.

[22] S. J. Harrison, A. M. McManus, J. P. Marcus et al., "Purification and characterization of a plant antimicrobial peptide expressed in Escherichia coli," Protein Expression and Purification, vol. 15, no. 2, pp. 171-177, 1999.

[23] C. F. Ajibola, J. B. Fashakin, T. N. Fagbemi, and R. E. Aluko, "Effect of peptide size on antioxidant properties of African yam bean seed (Sphenostylis stenocarpa) protein hydrolysate fractions," International Journal of Molecular Sciences, vol. 12, no. 10, pp. 6685-6702, 2011.

[24] J. Carrasco-Castilla, A. J. Hernandez-Alvarez, C. JimenezMartinez et al., "Antioxidant and metal chelating activities of peptide fractions from phaseolin and bean protein hydrolysates," Food Chemistry, vol. 135, no. 3, pp. 1789-1795, 2012.

[25] B. Wang, L. Li, C. F. Chi, J. H. Ma, H. Y. Luo, and Y. F. $\mathrm{Xu}$, "Purification and characterisation of a novel antioxidant peptide derived from blue mussel (Mytilus edulis) protein hydrolysate," Food Chemistry, vol. 138, no. 2-3, pp. 1713-1719, 2013.

[26] D. M. Marrufo-Estrada, M. R. Segura-Campos, L. A. ChelGuerrero, and D. A. Betancur-Ancona, "Defatted Jatropha curcas flour and protein isolate as materials for protein hydrolysates with biological activity," Food Chemistry, vol. 138, no. 1, pp. 7783, 2013.

[27] H. Schagger, H. Aquila, and G. Von Jagow, "Coomassie bluesodium dodecyl sulfate-polyacrylamide gel electrophoreis for direct visualization of polypeptides during electrophoresis," Analytical Biochemistry, vol. 173, no. 1, pp. 201-205, 1988.

[28] I. A. Holder and S. T. Boyce, "Agar well diffusion assay testing of bacterial susceptibility to various antimicrobials in concentrations non-toxic for human cells in culture," Burns, vol. 20, no. 5, pp. 426-429, 1994.

[29] W. Brand-Williams, M. E. Cuvelier, and C. Berset, "Use of a free radical method to evaluate antioxidant activity," LWT-Food Science and Technology, vol. 28, no. 1, pp. 25-30, 1995.

[30] T. Osawa and M. Namiki, "A novel type of antioxidant isolated from leaf wax of Eucalyptus leaves," Agricultural and Biological Chemistry, vol. 45, no. 3, pp. 735-740, 1981.

[31] C. Stephens, K. Kazan, K. C. Goulter, D. J. Maclean, and J. M. Manners, "The mode of action of the plant antimicrobial peptide MiAMP1 differs from that of its structural homologue, the yeast killer toxin WmKT," FEMS Microbiology Letters, vol. 243, no. 1, pp. 205-210, 2005.

[32] S. S. Verma, W. R. Yajima, M. H. Rahman et al., "A cysteine-rich antimicrobial peptide from Pinus monticola (PmAMP1) confers resistance to multiple fungal pathogens in canola (Brassica napus)," Plant Molecular Biology, vol. 79, no. 1-2, pp. 61-74, 2012.

[33] H. X. Wang and T. B. Ng, "An antifungal peptide from red lentil seeds," Peptides, vol. 28, no. 3, pp. 547-552, 2007.

[34] Y. Li, Y. Liu, Z. Zhou et al., "Complete genome sequence of Aeromonas veronii strain B565," Journal of Bacteriology, vol. 193, no. 13, pp. 3389-3390, 2011.

[35] I. Mora, J. Cabrefiga, and E. Montesinos, "Antimicrobial peptide genes in Bacillus strains from plant environments," International Microbiology, vol. 14, no. 4, pp. 213-223, 2011. 
[36] P. Dey, K. R. Maulik, M. M. Santi, and M. K. Mrinal, "Identification of an extracellular antifungal protein from the endophytic fungus Colletotrichum sp. DM06," Protein and Peptide Letters, vol. 20, no. 2, pp. 173-179, 2013.

[37] P. B. Pelegrini, L. R. Farias, A. C. M. Saude et al., "A novel antimicrobial peptide from crotalaria pallida seeds with activity against human and phytopathogens," Current Microbiology, vol. 59, no. 4, pp. 400-404, 2009. 

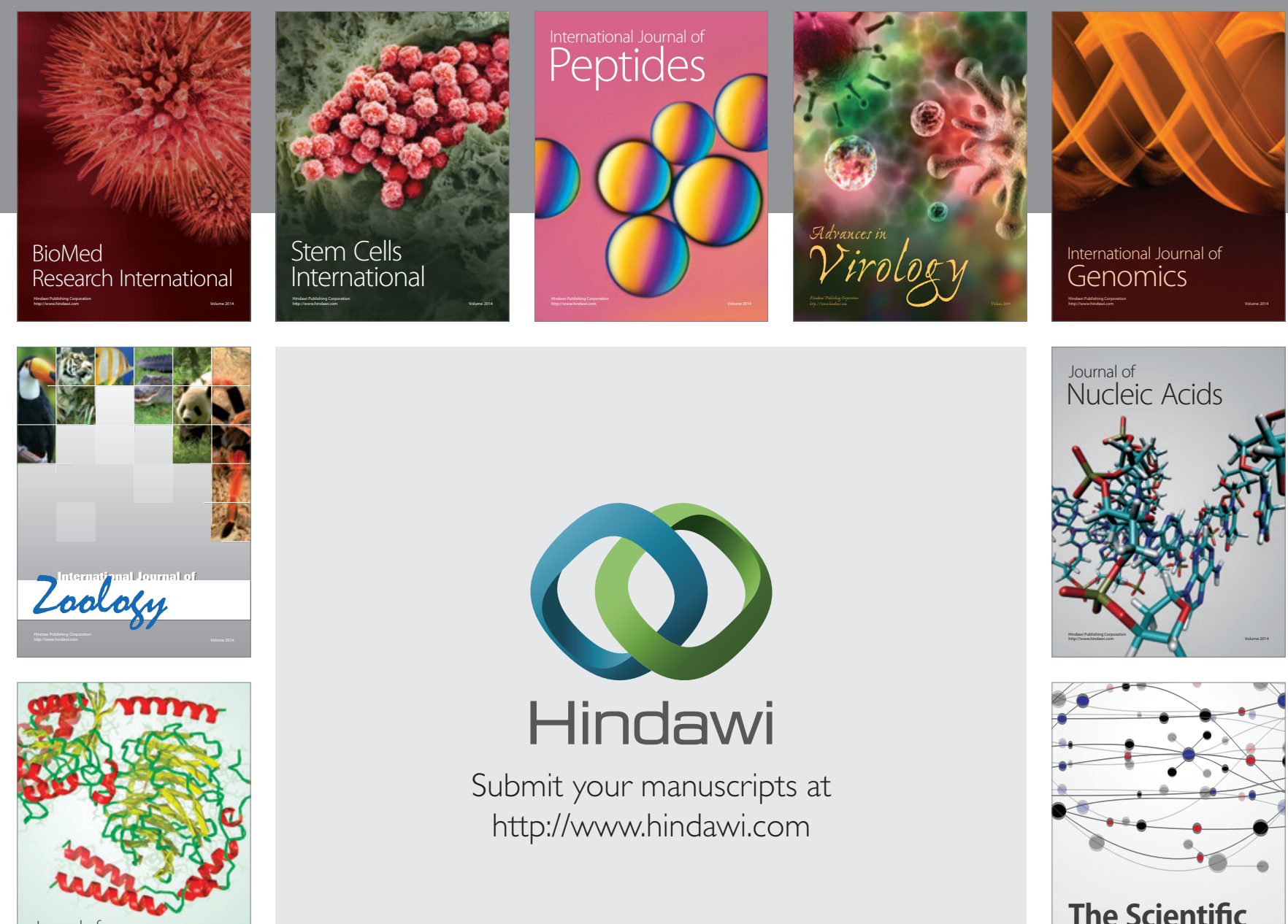

Submit your manuscripts at

http://www.hindawi.com

Journal of
Signal Transduction
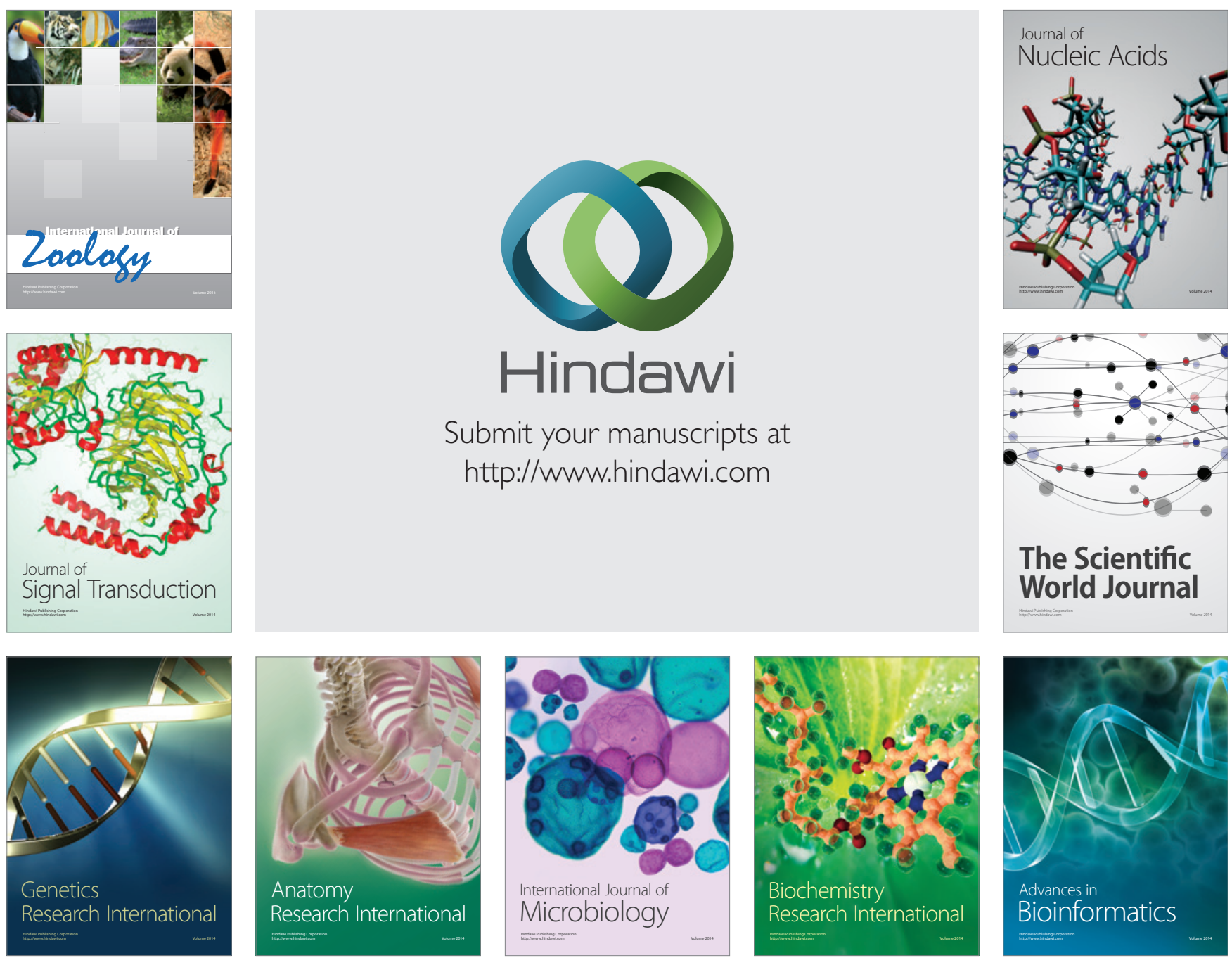

The Scientific World Journal
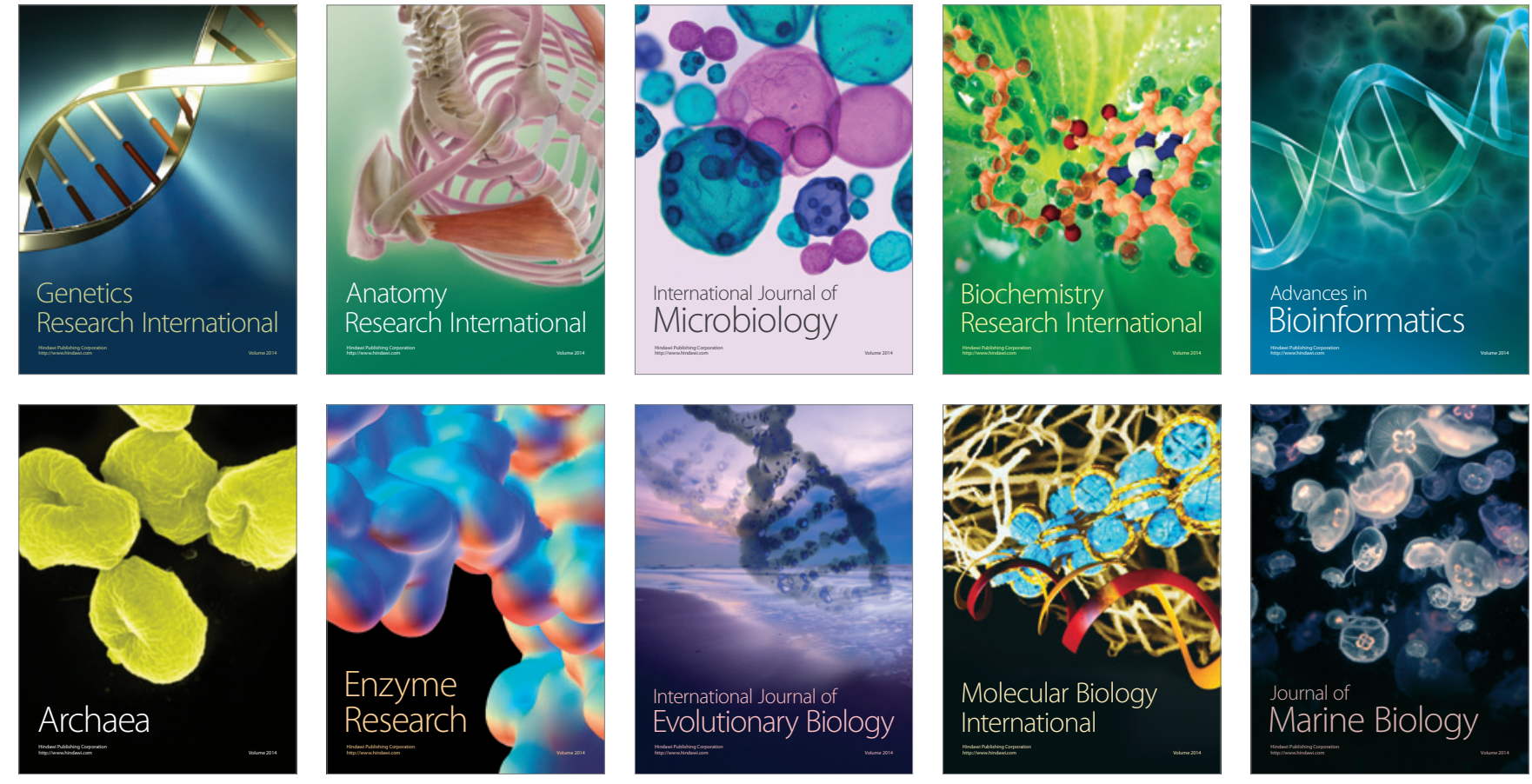